\title{
EFEKTIFITAS SOSIAL MEDIA INSTAGRAM @jokowi DALAM MEMBENTUK PERSONAL BRANDING PADA KAMPANYE PILPRES 2019
}

Adi Sugiantoro ${ }^{1}$, Mohammad Ghiarola Jamalullail Ramadhan ${ }^{2}$, Irsyad Abdul Maajid ${ }^{3}$, Ryandi Hadiansyah $^{4}$, Shabika Zukhruf Nurmalisi ${ }^{5}$, Mirza Shahreza ${ }^{6}$

Universitas Muhammadiyah Tangerang

adisugiantoro1025@gmail.com, ghiarolajammaluai@gmail.com, mjdirsyad@gmail.com, ryandyhady31@gmail.com, Zukhruf44@gmail.com, Mirzashahreza@,outlook.co.id

\begin{abstract}
Abstrak
Media adalah alat penting untuk membangun dan mempromosikan citra positif para kandidat dalam setiap pemilihan umum. Di tengah perkembangan luas media digital dan internet, kandidat presiden tidak hanya menggunakan media arus utama seperti televisi, radio, dan media cetak untuk mempromosikan citra mereka, tetapi juga menggunakan internet, dalam hal ini, media sosial untuk mendapatkan tujuan. Dalam pemilihan presiden Indonesia tahun 2019, Instagram menjadi media sosial populer yang digunakan oleh para kandidat untuk mempromosikan self-image. Dengan menggunakan teori dramaturgi, penelitian ini melakukan analisis teks terhadap konten politik yang dihasilkan oleh akun resmi Instagram Joko Widodo, @jokowi, 6 bulan sebelum pemilihan. Studi ini menunjukkan Jokowi menggunakan Instagram sebagai panggung depannya dengan membangun citra politik positifnya dengan menggunakan beberapa masalah termasuk keberhasilannya membangun infrastruktur, mempertahankan harga yang stabil di pasar tradisional, memperjuangkan kesejahteraan atlet, mendorong dana desa untuk mengembangkan desa-desa. Studi ini menerangkan bahwa sosial media instagram sangat efektif dalam membentuk personal branding pada saat kampanye. Studi ini menyarankan agar publik lebih kritis dalam membaca pesan kampanye politik pada kandidat presiden karena ini hanya memberikan masalah positif yang diidentifikasi sebagai tahap depan yang menyembunyikan kenyataan sebenarnya.
\end{abstract}

Keywords: Instagram, Pencitraan, Gambar Diri, Dramaturgi, Pemilihan Presiden 2019 


\section{PENDAHULUAN}

Di era perkembangan teknologi, proses sosialisasi atau kampanye politik sudah tidak lagi menggunakan media penyiaran dan media cetak melainkan menggunakan media sosial juga. Menurut (Hariati, 2014), next generation yang didominasi oleh anak-anak muda mencari informasi tentang politik dan pemili-han presiden, termasuk profil calon presiden lewat alat berupa gadget, smartphone, internet, dan jejaring sosial. Anak-anak muda mengakui, mereka merasakan sensasi yang berbeda ketika mencari informasi tentang politik melalui media sosial, seperti twitter facebook, intagram, youtube, dan jejaring so-sial dibandingkan mencari informasi melalui media penyiaran dan media cetak.

Beberapa tokoh politik memang pernah menggunakan media penyiaran sebagai sarana untuk merepresentasikan citra dirinya. Pada penelitian (Pratiwi, 2018) Hari Tanoesoedibyo merepresentasikan citra dirinya melalui iklan Partai Perindo yang tayang di stasiun-stasiun TV yang digawanginya. Simbol-simbol tentang Hari Tanoe begitu melekat pada atributatribut yang digunakan olehnya di iklan Partai Perindo. Atribut tersebut dikenakan olehnya untuk mendapatkan perhatian dari publik. Selain Hari Tanoe, Aburizal Bakrie juga menggam-barkan citra politik Partai Golkar melalui tayangan-tayangan di stasiun televisi yang berada di bawah naungannya, yakni TVOne dan juga media online yang masih berada dalam satu grup, viva.co.id. (Muchtar, 2016) menjabarkan bahwa Golkar menggunakan strategi kunjungan ke luar negeri sebagai salah satu sarana pencitraan. Tentunya hal itu diberikatan oleh viva.co.id dan TVOne pada 23 November 2011 dengan judul Golkar Jajaki Partai Berkuasa Thailand dan Golkar-UMNO Setuju Bantu Masalah Negara. Nara-sumber utama yang disorot oleh berita itu adalah Aburizal Bakrie yang berada di fraksi Golkar sekaligus pemilik saham yang sangat be-sar di Grup Bakrie.

Berdasarkan penjabaran di atas, dapat disimpulkan bahwa kampanye melalui stasiun televisi didominasi oleh para tokoh politik sekaligus pemilik dari perusahaan media besar di Indonesia. Lantas, bagaimana dengan tokoh-tokoh yang tidak memiliki afiliasi dengan mediamedia penyiaran? Tokoh politik yang ingin berkampanye, namun tidak memiliki 'benang merah' dengan stasiun televisi atau media cetak, tentunya harus mengeluarkan ongkos yang sangat besar untuk melakukan kampanye. Kehadiran media sosial merupakan jawaban dari pertanyaan di atas. (Mauludi, 2018) menuliskan, generasi di era teknologi seperti saat ini lebih mengenal media baru yang berbasis digital dan semakin mobile, bukan lagi bergantung sepenuhnya pada media penyiaran dan media cetak. Terlebih lagi, (Mauludi, 2018) menuliskan bahwa media sosial merupakan cerminan dari kultur masyarakat Indonesia yang bersifat paguyuban, suka bergaul, mengobrol, dan satu sama lain. Media sosial sendiri 
merupakan media online dimana para penggunanya dapat saling terhubung, berkomunikasi, berpartisipasi, berbagi, dan menciptakan konten dari media yang digunakan secara bersamasama tersebut.

Media sosial menjadi wadah yang tepat untuk melakukan political campaign.

Pasalnya, media sosial termasuk sarana komunikasi yang lebih murah dibandingkan media penyiaran dan media cetak. Namun, di sisi lain, (Ardha, 2014) menuliskan bahwa penggunaan media sosial dalam political campaign harus direncanakan sesuai dengan program-program yang telah disusun oleh tokoh politik dengan tujuan meningkatkan kredibilitas partai atau kredibilitas dari tokoh politik yang bersangkutan. Peluang ini mendorong tokoh-tokoh politik untuk membangun citra dirinya di media sosial, apalagi menjelang pemilihan umum. kampanye merupakan aktivitas persuasif yang diselenggarakan secara sadar, sengaja, bertahap, dan berkelanjutan dalam suatu periode waktu tertentu. Di Indonesia, penggunaan media sosial untuk melakukan kampanye pun tidak dilarang, bahkan belum ada aturan secara spe-sifik yang mengatur tentang hal itu. Dilansir dari (Kumparan.com, 2018), KPU tidak memberikan batasan untuk berkampanye melalui media sosial. Mereka hanya memantau pergerakan kampanye dari konstelasi politik yang berlangsung sebelum pemilihan berlangsung.

Oleh sebab itu, di tahun 2019 ini, calon presiden dan calon wakil presiden tidak hanya melaporkan tentang dana kampanye dan tim sukses dari kubu masing-masing ke KPU, tapi juga melaporkan tentang akun me dia sosial yang digunakan untuk berkampanye sehingga menjadi rujukan resmi masyarakat dalam memantau aktivitas capres dan cawapres. Pelaporan akun ini ditujukan agar melawan akun-akun hoax yang mengaku sebagai tim sukses dari masing-masing kubu. Untuk kampanye sendiri, dilansir dari (Kumparan.com, 2018), Joko Widodo dan Ma'ruf Amin tidak melaporkan akun milik pribadi mereka ke KPU, melainkan akun media sosial yang dibuat oleh tim sukses untuk keperluan kampanye. Untuk facebook.com, pasangan nomor 01 ini memiliki nama akun Jokowi-Amin. Sementara di Instagram, akun kampa-nye tersebut bernama Jokowi.Amin. Untuk twitter, kubu ini juga memiliki akun@jokowi_amin.

Berdasarkan pengamatan di akun Instagram @jokowi.amin pada 7 Juni 2019, akun ini memiliki 511 ribu followers. Foto dan video yang dipublikasikan hanya berjumlah 451 post. Untuk foto dan video yang diunggah di akun tersebut, paling tidak satu post foto atau video hanya menerima 3 ribu hingga 80 ribu likes. Berbeda halnya dengan akun Instagram milik Joko Widodo pribadi. Akun @jokowi memiliki 21 juta followers dan 1,377 postingan pada 7 Juni 2019. Ketika mengunggah foto atau video di akun tersebut, Joko Widodo dapat meraup 
ratusan ribu likes. Melihat hal tersebut, tentunya Joko Widodo lebih mudah dalam membangun citra dirinya melalui Instagram pribadinya. Joko Widodo sudah memiliki jutaan followers dan Instagram miliknya sudah lama dibuat dibandingkan Instagram @jokowi.amin yang baru di-luncurkan pada masa kampanye capres dan cawapres di tahun 2018 kemarin.

Terkait pembangunan citra diri capres di media sosial, (Hasfi et al., 2017) menjabarkan bahwa di tahun 2014, Joko Widodo sudah memanfaatkan twitter untuk membangun citranya. Joko Widodo menjadikan twitter sebagai wadah untuk merepresentasikan gambaran capres yang dekat dengan masyarakat, salah satunya dengan mengunggah foto-foto ketika Joko Widodo bersalaman dengan masyarakat secara langsung. Efeknya, menjabarkan, anak-anak muda yang tergabung dalam pemilih pemula di Kota Malang pada tahun 2014 memberikan persepsi positif untuk political personal branding pada Joko Widodo. Informasi tentang Joko Widodo pun didominasi oleh informasi yang diperoleh anak-anak muda melalui internet dan twitter sebagai jejaring sosial yang sering digunakan oleh anak-anak muda di Kota Malang. Persepsi anak-anak muda tentang Joko Widodo selalu dikaitkan dengan baju kotak-kotak khas Joko Widodo yang melambangkan kesederhanaan. Joko Widodo berhasil membangun citra positif di kepala anak-anak muda.

Perkembangan teknologi media terlihat mengubah strategi para calon presiden dan wakil presiden untuk melakukan manajemen kesan pada diri mereka. Pada pemilihan presiden tahun 2009, sebagian besar penelitian di bidang komunikasi massa lebih condong menggambarkan representasi citra politik melalui media penyiaran dan media cetak. Sementara itu, pada pemilihan presiden di tahun 2014 menggambarkan bahwa twitter merupakan media sosial yang digunakan oleh tokoh politik untuk membangun citranya. Di tahun 2019 ini, calon presiden Joko Widodo tidak luput ketika melihat peluang untuk memanfaatkan beberapa media sosial yang dige-mari oleh anak-anak muda, salah satunya Instagram. Instagram tentu memiliki beberapa keunggulan sehingga digandrungi anak-anak muda, salah satunya keunggulan audio-visual dan jumlah karakter yang tidak terbatas. Berbeda halnya dengan twitter yang memiliki karakter hanya 280 huruf.

Untuk itu, penulis akan membahas tentang upaya Joko Widodo dalam personal branding melalui akun Instagram pribadi miliknya. Tujuannya adalah menganalisis tentang strategi Joko Widodo ketika menampilkan dirinya di Instagram sehingga meraup puluhan ribu likes, dimana hal ini akan mendorong pembentukan citra diri yang positif menjelang pilpres 2019 . Tidak menutup kemungkinan bahwa citra yang positif dari Joko Widodo menyebabkan dirinya menjadi pemenang pada pilpres 2019 ini. 


\section{KAJIAN PUSTAKA}

\section{Kajian Konseptual}

Tokoh politisi yang mempresentasikan dirinya untuk pemilihan presiden di tahun 2019 ini menarik untuk dipelajari dengan menggunakan teori komunikasi, terutama ketika merujuk pada teori dramaturgi karya Erving Goffman. (Atmaja \& Ariani, 2018) menuliskan, teori dramaturgi merupakan teori yang menjelaskan bahwa masyarakat adalah panggung depan dalam permainan sandiwara. Manusia bermain pada panggung depan berbentuk interaksi sosial dengan status dan peran yang berbeda-beda. Permainan di atas panggung tersebut terikat oleh motif dan/atau tujuan masing-masing.

Sementara itu, menurut (Devito, 1997) front stage merupakan panggung pertunjukan sebagai orang menonton para aktor ketika berperan di dalam sebuah pertunjukkan. Adapun lawan katanya adalah back stage, yakni aktivitas dan karakter aktor yang tidak boleh dilihat oleh penonton. juga menuliskan bahwa front stage terdiri dari setting dan front personal. Adapun setting yang dimaksud adalah hal-hal bersifat fisik yang tampak ketika aktor memainkan peran, seperti dokter yang bermain peran di kamar operasi, atau pilot yang bermain peran di dalam pesawat.

Selain setting, teori dramaturgi juga menganalisis tentang front personal. (Jazuli.M, 2014) menuliskan bahwa front personal terdiri atas berbagai macam barang perlengkapan yang berfungsi untuk menyatakan atau mengenalkan peran aktor kepada penonton dan perlengkapan itu sesuai dengan identitas peran yang dimainkan oleh sang aktor. (Atmaja \& Ariani, 2018) menyebutkan bahwa gagasan dari teori dramaturgi bisa diperluas, tidak hanya menunjukkan frontstage di panggung saja, namun juga melihat artefak tambahan untuk para aktor. Artefak tersebut tertuju pada aksesoris tambahan yang digunakan oleh aktor tersebut untuk memainkan perannya.

menuliskan bahwa jarak peran antara aktor dengan audiens. Orang-orang yang berstatus sosial tinggi cenderung menunjukkan jarak sosial karena alasan yang berbeda dengan orang yang berstatus lebih rendah. Hal ini terlihat pada aktor ketika berada di hadapan audiens atau pada tahap front stage. Selain Itu, unit analis pada teori dramaturgi adalah tim rahasia di balik layar. Tim ini terdiri dari sekumpulan individu yang bekerjasama dalam suatu pertunjukkan rutin, sehingga konsep aktor bukanlah bersifat tunggal melainkan bersifat tim. Tim tersebut menjadi 'masyarakat rahasia' yang mengaburkan fakta-fakta penting ketika aktor berinteraksi dengan audiens. 
Teori dramaturgi merupakan acuan untuk menurunkan teori-teori lainnya, salah satunya teori impression management. (Kriyantono, 2014) menuliskan, teori ini menyebutkan bahwa dalam interaksi sosial, setiap individu berupaya menampilkan gambaran dirinya di depan orang lain. Upaya manajemen impresi ini menggambarkan bahwa individu secara sengaja menggunakan komunikasi untuk menciptakan kesan yang di-inginkan dari orang lain terhadap dirinya. Hal ini sesuai dengan teori dramaturgi yang di-jelaskan di atas, yakni aktor memainkan aktingnya di panggung sesuai dengan tujuan masing-masing.

Konsep presentasi diri dari dramaturgi yang dikemukakan oleh Goffman dan impression management yang dikemukakan oleh Johannson dalam buku (Kriyantono, 2014) menghasilkan strategi-strategi yang diyakini dilakukan oleh individu untuk mempresentasikan diri dan membangun kesan di depan orang lain. di dalam (Kriyantono, 2014) menuliskan tipologi presentasi diri sebagai berikut:

1. Strategi ingratitation. Strategi Ini digunakan oleh individu yang ingin dipersepsi sebagai pihak yang menyenangkan atau ramah.

2. Strategi self-promotion. Strategi ini digunakan oleh individu yang ingin diimpresikan sebagai individu yang berkompeten.

3. Strategi exemplification. Strategi digunakan oleh individu yang ingin diimpresikan sebagai organisasi atau tokoh yang layak dijadikan contoh atau model bagi orang lain.

4. Strategi supplication. Strategi ini biasanya digunakan oleh organisasi atau individu yang memiliki keterbatasan dalam membantu publik. Individu menunjukkan dirinya sebagai sebagai pihak lemah dan pihak yang yang menjadi korban dari krisis yang terjadi.

5. Strategi intimidation. Pada umumnya, individu yang menggunakan strategi ini dipersepsi sebagai organisasi yang kuat dan mampu mengontrol situasi.

\section{METODOLOGI PENELITIAN}

Penelitian ini menggunakan pendekatan deskriptif kualitatif untuk menjawab pertanyaan penelitian ini, yakni melihat bagaimana strategi Joko Widodo dalam membangun manajemen kesan sebagai presiden dan calon presiden RI pada tahun 2019 melalui akun Instagram miliknya. Penelitian ini hanya fokus mengamati post Instagram milik Joko Widodo pada masa kampanye hingga pemilihan presiden RI pada 1 Oktober 2018 hingga 17 April 2019. Adapun akun media sosial Instagram yang diteliti adalah akun@jokowi.

Penelitian ini akan menganalisis secara deskriptif tentang konten-konten di Instagram milik Joko Widodo pada rentang waktu tertentu. Penelitian ini mendeskripsikan sesuai dengan konsep teori dramaturgi dan impression management, yakni melihat front stage dari 
Joko Widodo di Instagram, mendeskripsikan jarak sosial yang tercipta antara Joko Widodo dan audiens, mendeskripsikan artefak dari Joko Widodo, tim rahasia yang berada di belakang panggung Instagram Joko Widodo. Setelah itu, penelitian ini akan mendeskripsikan tentang strategi manajemen kesan yang digunakan oleh Joko Widodo. Strategi tersebut sesuai dengan tipologi yang dijabarkan oleh Metts, (Kriyantono, 2014), yakni strategi ingratiation, strategi self-promotion, strategi exemplification, strategi supplication, dan strategi intimidation.

\section{PEMBAHASAN}

\section{Front Stage Joko Widodo}

Berdasarkan hasil pengamatan penulis sejak masa kampanye hingga pemilihan presiden, yakni rentang waktu 1 Oktober 2019 hingga 31 Desember 2019, Joko Widodo memposting 525 foto dan video di Instagram @jokowi. Pada 8 Juni 2019, akun tersebut telah memposting 1373 post dan memiliki 21 juta pengikut. Dalam rentang waktu Oktober hingga April 2019, Joko Widodo paling banyak mem-posting tentang peresmian dan perkembangan infrastruktur di negara Indonesia. Selain itu, Joko Widodo juga sering mengunggah video maupun gambar tentang kegiatan blusukan ke pasar-pasar tradisional. Dari foto yang dipost-ing di Instagram miliknya, tampak Joko Widodo sedang mengobrol dengan pedagang-pedagang di pasar tradisional dan menjabat tangan mereka. Selain blusukan ke pasar tradisional, Joko Widodo juga mengunggah postingan tentang kegiatannya di berbagai ko-ta di Indonesia, seperti di tugu 0 kilometer di Merauke, kegiatan pertemuan tahunan IMF-World Bank di Bali, hingga kunjungan di KTT Asian-Rusia. Dari beragam post tersebut, tak jarang Joko Widodo mengunggah potretnya yang sedang menggendong anak kecil, dan memegang bahu para lansia sambil mendengarkan apa yang mereka katakan.

Selain memposting kegiatan tentang dirinya di lapangan, Instagram Joko Widodo juga memposting tentang hari-harinya bersama keluarga. Joko Widodo terlihat sering mengunggah gambar ketika ia menggandeng tangan Ibu Iriana Widodo, menggendong cucunya Jan Ethes, dan menghabiskan waktunya bersama keluarga di Istana Bogor maupun di Solo. Sesuai dengan (Atmaja \& Ariani, 2018), teori dramaturgi menggambarkan tentang manusia yang bermain di panggung depan, dimana mereka bermain dengan cara melakukan interaksi sosial dengan status dan peran yang berbeda-beda. Peran yang dimainkan tersebut terikat oleh motif dan tujuan dari aktor tersebut. Untuk penelitian ini, Joko Widodo bermain peran sebagai calon presiden yang akan menghadapi pemilu. Sebagai capres, Joko Widodo menjadikan Instagram sebagai panggungnya dan followers serta pemilik akun Instagram lainnya sebagai 
penonton. Ia harus berperan seapik mungkin di Instagram agar tujuannya tercapai, yakni memproleh suara yang lebih dari 50 persen untuk memenangkan pemilu 2019 ini.

Di Instagram miliknya, Joko Widodo sering mengunggah tentang pencapaiannya dalam membangun infrastruktur. Berdasarkan pengamatan di Instagram miliknya, Joko Widodo memposting kurang lebih 90 foto dan video tentang infrastruktur, seperti video ten-tang Jalan Tol Trans Jawa, fotonya di jembatan Holtekamp Jayapura, foto Joko Widodo ketika meresmikan tol di Lampung, dan lain sebagainya. Post tersebut mendapat ratusan ribu likes dari para pengguna Instagram.

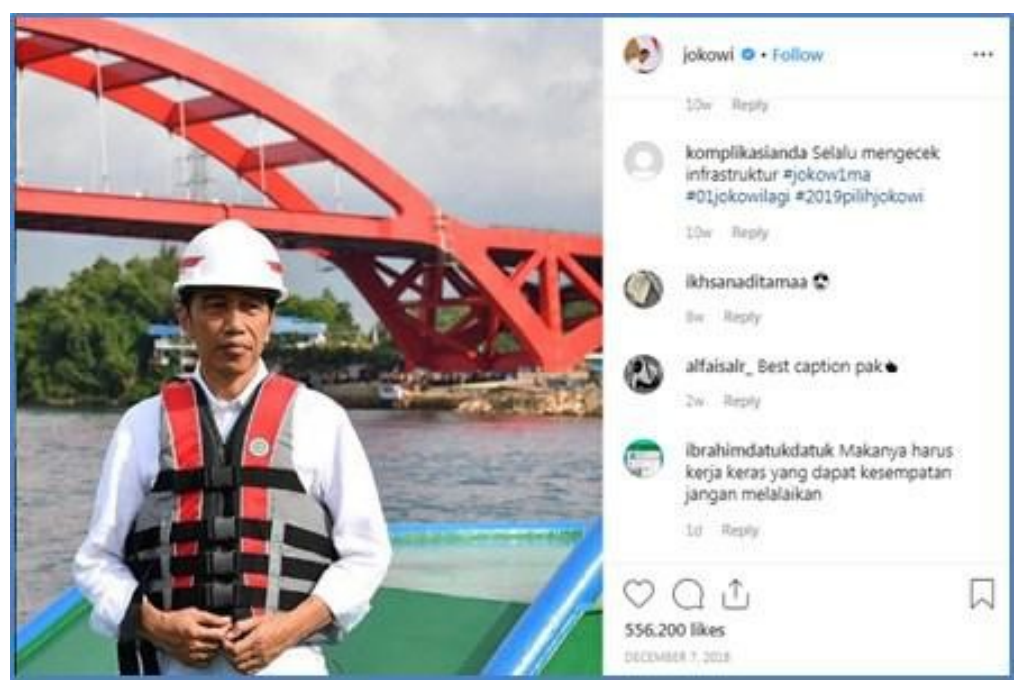

Gambar 1. Joko Widodo mengunggah fotonya yang sedang berdiri di depan Jembatan Holtecamp di Jaya-pura. Jembatan itu adalah infrastruktur yang telah dibangun para era kepemimpinannya. Gambar ini diunggah pada 7 Desember 2018.

Joko Widodo tidak hanya mengunggah foto dan video tentang pembangunan infrastruktur yang berhasil diresmikan dan dini-kmati masyarakat. Joko Widodo juga mengunggah foto-foto ketika melakukan blusukan ke pasar tradisional. Istilah 'blusukan' menjadi atribut khas Joko Widodo sejak menjadi walikota Solo dan gubernur DKI Jakarta. Kata 'blusukan' begitu identik dengan kegiatan Joko Widodo yang melakukan interaksi dengan masyarakat secara langsung.

Berdasarkan temuan di Instagram @jokowi, terlihat bahwa Joko Widodo sering melakukan kunjungan ke pasar-pasar tradisional dan berbincang dengan para pedagang di sana. Joko Widodo terlihat akrab dengan para pedagang di pasar tradisional tersebut. Untuk 
konten Instagram bertema blusukan ini, Joko Widodo berhasil meraup ratusan ribu likes dari followers dan para pengguna akun Instagram lainnya.

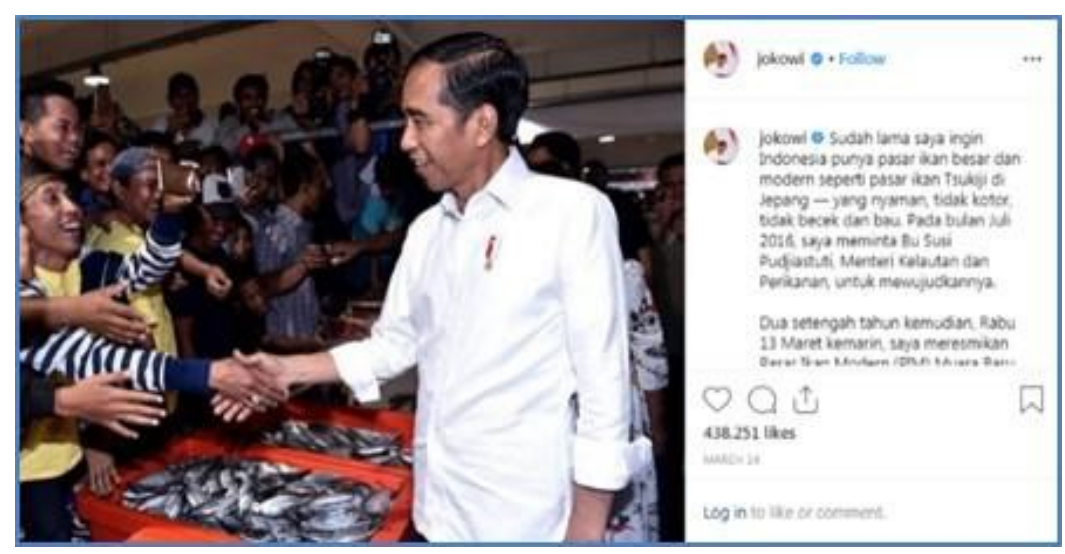

Gambar 2. Potret Joko Widodo tentang kegiatan blusukan ke pasar tradisional. Foto ini diunggah pada 14 Maret 2019 di Pasar Ikan Muara Baru, Jakarta Utara.

Tak hanya konten berupa infrastruktur dan blusukan, tapi konten Instagram Joko Widodo tentang kunjungan ke lokasi bencana alam juga menghiasi dinding Instagram miliknya. Pada awal Oktober, Joko Widodo memposting potretnya di lokasi bencana di Palu dan Donggala, Sulawesi Tengah. Selain di Palu dan Donggala, Joko Widodo juga mengunggah fotonya ketika relokasi bencana di Lombok, Nusa Tenggara Barat, dan juga memposting potretnya ketika mengunjungi Provinsi Banten yang terkena bencana tsuna-mi di akhir tahun 2018.

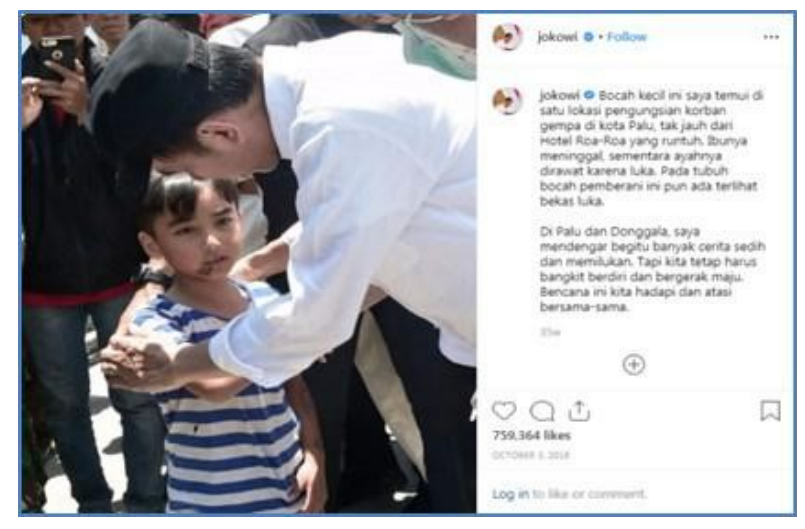

Gambar 3. Joko Widodo mengunggah fotonya ketika berinteraksi dengan salah satu korban gempa di Palu, Sulawesi Tengah. Foto ini diunggah pada 3 Oktober 2018. 
Joko Widodo mengunggah potretnya ketika sedang berada di lokasi pengungsian Banten. Ia juga mengunggah fotonya ketika memberikan beasiswa untuk ribuan maha-siswa di Lombok yang tidak bisa me-nyelesaikan kuliahnya akibat gempa. Selain itu, pada konten tentang bencana alam, Joko Widodo juga mengunggah potretnya dengan anak kecil yang menjadi salah satu korban bencana alam di Sulawesi Tengah.

Unggahan tentang penggunaan dana desa juga cukup banyak ditemui di Instagram milik Joko Widodo. Dari foto dan video yang diunggah di Instagram, para followers dan pengguna Instagram lainnya dapat melihat bahwa Joko Widodo mendatangi langsung lokasi tempat dana desa tersebut di-pergunakan. Selain potret tentang dirinya sendiri yang mendatangi tempat realisasi dana desa, Joko Widodo juga memposting potret mengenai tempat-tempat wisata di Indonesia yang berhasil dibangun dengan menggunakan dana desa.

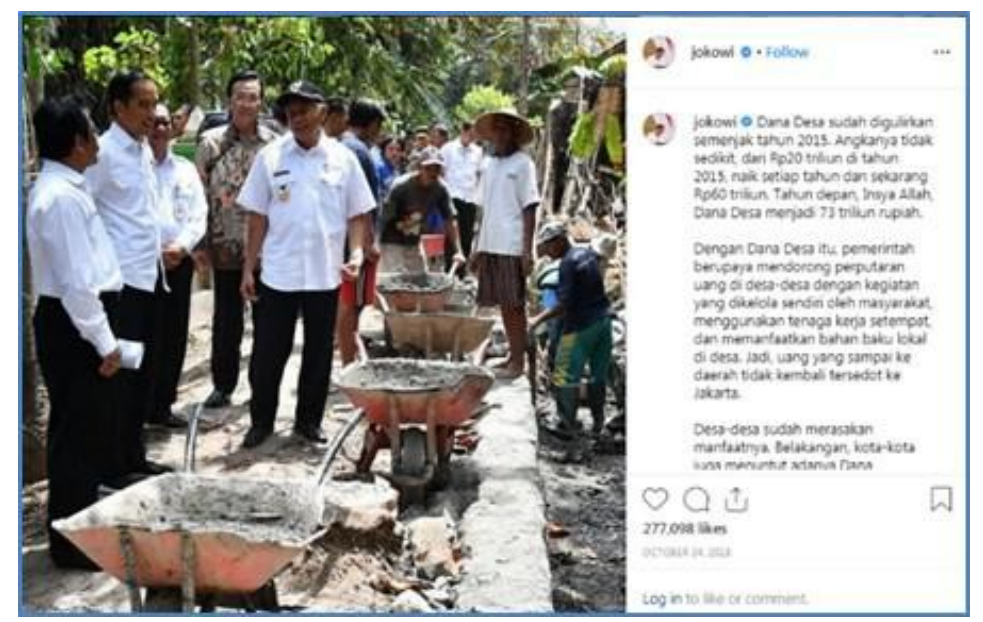

Gambar 4. Joko Widodo mengunggah foto tentang pembangunan di salah satu kampung dengan menggunakan dana desa. Foto tersebut diunggah pada 24 Oktober 2018.

Selain tentang dana desa, Instagram milik orang nomor satu di negara Indonesia ini juga memposting kegiatan-kegiatan yang melibatkan atlet-atlet berbagai cabang olahraga. Pada era Joko Widodo menjabat menjadi presiden, Indonesia menjadi tuan rumah untuk Asian Games 2018 dan Asian Para Games 2018. Melalui konten Instagram miliknya, Joko Widodo tak pernah bosan un-tuk mengunggah fotonya bersama para atlet dan caption yang selalu diakhiri dengan ka-limat, "Selamat berjuang!". Selain atlet Asian Games dan Asian Para Games, Joko Widodo juga mengunggah potretnya dengan tim sepakbola Garuda Indonesia. Unggahan beru-pa foto dan video antara Joko Widodo dan atlet-atlet tersebut meraih ratusan ribu likes di Instagram. 


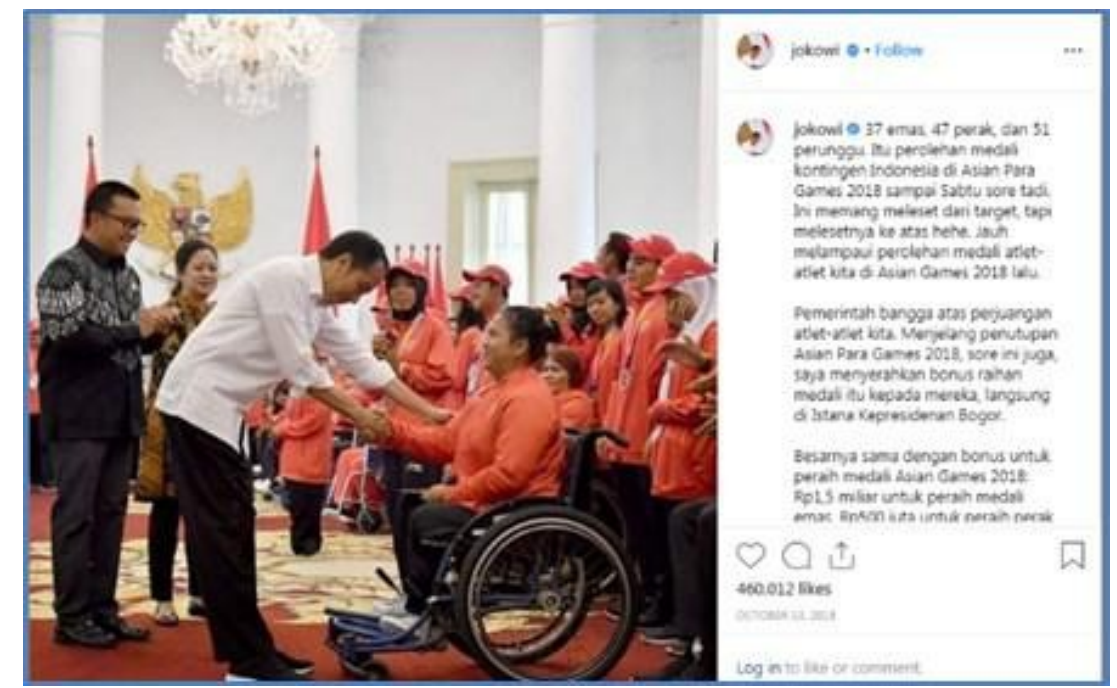

Gambar 5. Foto Joko Widodo ketika sedang menyalami salah satu atlet Asian Para Games 2018. Foto ini diunggah pada 13 Oktober 2018

Di Instagram miliknya, Joko Widodo tidak hanya memainkan peran sebagai pemimpin sebuah negara dan calon presiden, tetapi juga sebagai pemimpin keluarganya. Pada post di Instagram miliknya, Joko Widodo juga mempublikasikan tentang kemesraan dengan istrinya, Iriana Widodo yang mendamping-inya. Joko Widodo juga memposting ketika ia dan keluarganya sedang jalan pagi di Istana Bogor. Selain itu, ia juga mengunggah foto dan video ketika sedang bermain dengan anak dan cucunya.

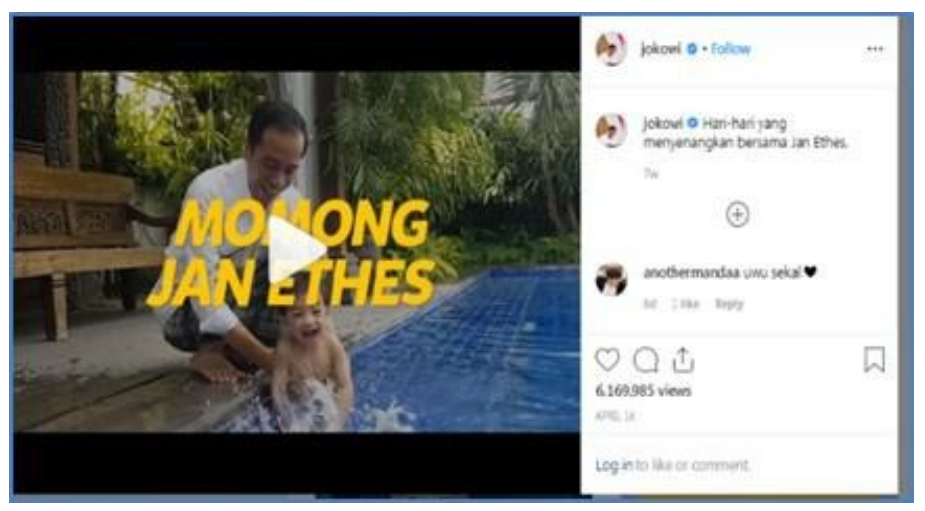

Gambar 6. Joko Widodo mengunggah foto dan video ketika ia menghabiskan waktu santai bersama keluarganya. Video ini diunggah pada 16 Maret 2019

Joko Widodo adalah aktor yang memainkan peran sebagai calon presiden di panggung bernama Instagram. Joko Widodo juga menunjukkan bahwa ia berperan sebagai presiden 
Indonesia sejak tahun 2014-2019, sebagai suami dari Iriana, sebagai ayah, dan juga kakek dari cucu-cucunya. Hal itu dit-ampilkan oleh Joko Widodo pada Instagram miliknya. Pada foto dan video yang ditampilkan di Instagram, Joko Widodo memperlihatkan bahwa ia tidak memiliki jarak dengan rakyat, meskipun statusnya adalah orang nomor satu di Indonesia. Pernyataan itu didukung oleh foto dan video yang diposting ketika Joko Widodo blusukan ke pasar tradisional, dimana Joko Widodo berbicara dengan pedagang tanpa ada sekat yang membatasi. Namun, di sisi lain, ketika Joko Widodo berperan sebagai calon presiden dan melakukan kampanye, ia berdiri di atas panggung sehingga tercipta ja-rak antara dirinya

dengan audiens.

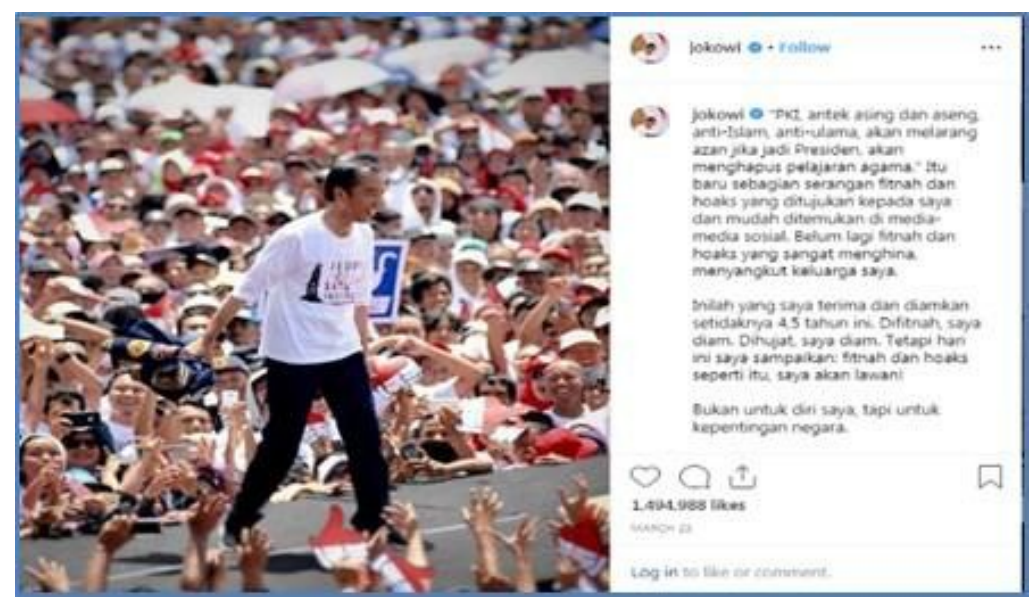

Gambar 7. Joko Widodo mengunggah foto dan video ketika ia berkampanye di hadapan masyarakat. Joko Widodo berdiri di atas panggung dan menjadi titik perhatian penonton.

Foto ini diunggah pada 23 Maret 2019.

Selain itu, di Instagram milik Joko Widodo, ia tidak pernah membalas satu pun komentar dari warganet, baik komentar positif maupun negatif. Hal ini menunjukkan bahwa Joko Widodo menciptakan jarak antara audiens dengan dirinya yang berperan sebagai presiden RI dan calon presiden. Setting dari foto dan video yang ditampilkan Joko Widodo di Instagram cukup beragam. Joko Widodo terkadang berada di pasar tradisional, berada di markas TNI, di acara-acara besar seperti IMF Bali-World Bank, di lokasi bencana alam, bahkan hingga di luar negeri, mulai dari Singapura hingga Arab Saudi. Hal ini sesuai dengan peran Joko Widodo sebagai aktor. Peran sebagai presiden dan calon presiden tidak memiliki setting yang tetap untuk menunjukkan perannya, seperti dokter yang memiliki setting di rumah sakit. Hal ini sesuai dengan UUD 1945, dimana presiden memiliki kedudukan sebagai kepala negara 
dan kepala pemerintahan. Bukan hal yang aneh ketika presiden memantau perkembangan masyarakat di lapangan dan menghadiri undangan dari pemimpin negara-negara lain.

Adapun artefak yang melekat pada Joko Widodo adalah baju berwarna putih. Di Instagram miliknya, hampir seluruh potretnya memperlihatkan bahwa Joko Widodo mengenakan pakaian berwarna putih yang lengannya digulung. Warna putih telah menjadi identitas bagi Joko Widodo sejak menggulung lengannya, artinya ia siap bekerja dengan hati yang bersih untuk kebaikan masyarakat Indonesia. Hal ini sesuai dengan slogan dari Jokowi: kerja, kerja, kerja! Terkait tentang keberadaan 'masyarakat rahasia' di belakang Instagram Joko Widodo, akun tersebut dikelola oleh tim. Di profile Instagram milik Joko Widodo, tertulis bahwa akun tersebut dikelola oleh Tim Komunikasi Digital Presiden. Hal ini sesuai dengan teori dramaturgi, dimana tim komu-nikasi digital presiden terdiri dari individu-individu yang bersama-sama mendorong aktor untuk meraih tujuan yang ingin dicapai oleh aktor tersebut. Konsep Joko Widodo dalam memainkan peran sebagai presiden dan calon presiden ini bersifat tim, dimana tim tersebut menjadi 'masyarakat rahasia' yang bergerak di belakang layar ketika Joko Widodo berinteraksi dengan audiens. Panggung Joko Widodo dikelola oleh tim di belakang layar yang tidak boleh terlihat oleh para audiens.

Strategi dalam Membangun Personal Brand

Pada 9 November 2018, Joko Widodo memposting foto dan tulisan bahwa ia telah meresmikan jalan tol Pejagan-Pemalang di segmen Brebes Timur-Sewaka dan jalan tol Pemalang-Batang pada segmen Sewaka-Simpang Susun Pemalang di Tegal. Selanjutnya, pada 28 November 2018, Joko Widodo menuliskan tentang beroperasinya ruas tol segmen Sragen-Ngawi sepanjang 51 kilometer. Tol tersebut merupakan bagian dari Jalan Tol Trans Jawa yang dimulai dari Merak di Banten dan berakhir di Surabaya, Jawa Timur. Pada caption dari unggahan tersebut, Joko Widodo menuliskan, "Dalam empat tahun terakhir, konektivitas di negara Indonesia se-makin terwujud. Satu demi satu, daerah demi daerah, wilayah demi wilayah, pulau demi pulau, semakin terintegrasi dengan pelabuhan, jalan, dan bandara".

Joko Widodo kembali mengunggah foto dan tulisan yang menunjukkan bahwa ia telah meresmikan tol menuju Sukabumi, Jawa Barat. Melalui postingan tersebut, Joko Widodo menuliskan bahwa tol Bogor-Ciawi-Sukabumi (Bocimi) yang terbengkalai selama 20 tahun, kini telah diresmikan oleh Joko Widodo dengan segmen Ciawi-Cigombong dengan jarak kurang lebih 15,35 kilometer. Selain jalan tol, pada tanggal 7 Desember 2018, Joko Widodo memposting fotonya di Jayapura, tepatnya dengan latar belakang Jembatan Holtekamp yang 
memiliki panjang 1.800 meter dan menjadikan jarak antara Jayapura dan perbatasan menjadi dekat. Joko Widodo menuliskan pada caption dari foto tersebut, "Itulah mengapa infrastruktur jalan di Papua, Kalimantan, Sumatera, dan lain-lain, harus dibangun sebaik Pulau Jawa. Dengan keterhubungan antar wilayah yang bagus: orang Aceh semakin mengenal orang Papua, orang Papua harus kenal orang Kali-mantan, orang Kalimantan harus kenal orang Jawa, orang Jawa harus kenal orang Sulawe-si”.

Selanjutnya, pada 20 Desember 2018, akun milik Joko Widodo menampilkan potret Joko Widodo ketika meresmikan empat ruas jalan tol Trans Jawa di Jombang, Jawa Timur. Pada postingan tersebut, Joko Widodo menu-liskan, "Sejak hari ini, jalan tol Jakarta-Surabaya sudah tersambung dan bisa dilalui kendaraan. Saya sendiri dengan menggunakan bus Damri, pagi ini menjajal ruas tol yang jadi bagian dari Trans Jawa ini, dari Surabaya melewati Mojokerto, Kerto-sono, Ngawi, Sragen, Solo, Salatiga, Sema-rang, sampai perbatasan Kendal dan Batang. Jalan sepanjang 380 kilometer ini mulus. Bus yang saya tumpangi melaju cepat sampai $90 \mathrm{~km} / \mathrm{jam} ”$.

Pada tanggal 8 Maret 2019, Joko Widodo memposting fotonya bersama rom-bongan ketika tiba di Bandar Udara Lampung. Joko Widodo menjelaskan bahwa ia meresmi-kan tol sepanjang 140,9 kilometer dari Bakauheni sampai Terbanggi Besar di Lampung. Ia meresmikan gerbang tol Natar, Lampung Se-latan. Berikutnya, pada 13 Maret 2019, Joko Widodo memposting foto yang berlatar belakang Muara Gembong, Bekasi. Joko Widodo menegaskan bahwa dalam waktu em-pat tahun terakhir, pemerintah Indonesia gen-car membangun jembatan yang menjadi ikon daerah seperti Jembatan Holtekamp Jayapura dan Jembatan Kali Kuto di ruas tol Batang-Semarang, hingga jembatan yang dibangun sematamata untuk menunjang arus logistic dan konektivitas tranpsortasi. Joko Widodo menuliskan, "Itu pula sebabnya, empat tahun terakhir kita gencar membangun jembatan. Jika disambungkan, panjangnya 41.063 me-ter. Lebih dari 41 kilometer!”

Selanjutnya, untuk konten Instagram dengan tema blusukan, Joko Widodo juga memposting tentang keberhasilannya dalam menjaga harga komoditas pasar, dimana harga tersebut dapat dinikmati oleh seluruh masyarakat dari berbagai lapisan. Pada tang-gal 31 Oktober 2018, Joko Widodo mempost-ing fotonya saat berinteraksi dengan pedagang di pasar tradisional Jalan Roda, Bogor. Joko Widodo menceritakan bahwa harga di pasar berada dalam kondisi stabil. Ia menuliskan, "Harga komoditas di pasar yang saya temui ini sejalan dengan kondisi makro ekonomi kita, sesuai dengan besaran inflasi yang di bawah 3,5 persen. Inflasi stabil, harga di pasar juga stabil”. Pada 11 November 2018, Joko Widodo memposting foto tentang blusukan di Pasar Cihaurgeulis Bandung. Melalui postingan ter- 
sebut, Joko Widodo menekankan bahwa harga harga bahan pokok di Bandung masih stabil. Sementara itu, pada tanggal 20 November 2018, Joko Widodo memposting tentang dirinya yang memantau perkembangan harga bahan pokok dan pangan dengan cara berkunjung ke pasar untuk melihat harga-harga ba-han pokok. Pada post tersebut, ia menegaskan bahwa harga-harga di pasar menunjukkan skala normal. Pada unggahan tersebut, Joko Widodo menekankan, jika harga naik sedikit, Joko Widodo meminta kementerian terkait untuk turun langsung ke lapangan dan melakukan operasi pasar. Hal ini mengindi-kasikan bahwa harga yang stabil merupakan salah satu kegiatan yang dapat membangun kesan positif terhadap citra Joko Widodo.

Terkait post mengenai bencana alam, Joko Widodo memposting beberapa potretnya dengan latar belakang lokasi gempa di Sulawesi Tengah, Nusa Tenggara Barat, dan Banten. Tanggal 2 Oktober, Joko Widodo memposting potretnya ketika sedang berjalan di salah satu kecamatan di Palu yang luluh lantak oleh gempa dan tsunami. Di bawah potret tersebut, ia menyampaikan tentang ucapan bela sungkawa dari tokoh-tokoh internasional untuk Sulawesi Tengah, antara lain dari Raja Arab Saudi Salman bin Abdulaziz Al Saud, Presiden Rusia Vladimir Putin, Perdana Menteri Singapura Lee Hsien Loong dan Presiden Singapura Halimah Yacob, dan lainnya.

Sementara itu, pada tanggal 3 Oktober, Instagram milik presiden tersebut memposting kembali tentang potretnya ketika berinteraksi bersama TNI, Basarnas, dan tim PUPR yang menyediakan alat berat untuk membongkar bangunan-bangunan guna mencari jasad. Joko Widodo memberikan instruksi tentang langkah-langkah agar mereka segera melakukan aksi evakuasi cepat di Palu, seperti pencarian korban, pemenuhan keburuhan dasar logistik untuk pengungsi, dan perbaikan infrastruktur serta layanan umum di kawasan bencana. Postingan Joko Widodo di Palu pun terus berlanjut hingga tanggal 4 Oktober 2018, yakni potret Joko Widodo menggendong anak kecil yang berada di pengungsian dekat Hotel Roa-Roa, dimana tubuh anak kecil tersebut penuh dengan bekas luka akibat gempa.

Postingan Joko Widodo tentang bencana alam berlanjut pada tanggal 18 Ok-tober 2018, ketika Joko Widodo datang ke Lombok, Nusa Tenggara Barat untuk melihat pemulihan bencana di sana. Postingan tersebut menceritakan bahwa Joko Widodo menyeder-hanakan pencairan uang bantuan, dimana pen-cairan tersebut membutuhkan 17 langkah, na-mun kini disederhanakan menjadi satu langkah. Selain itu, terkait pemulihan pasca bencana di Lombok, Joko Widodo juga mem-posting foto dan menuliskan caption bahwa ia menyerahkan bantuan pendidikan kepada tujuh mahasiswa Lombok yang mewakili ribuan mahasiswa Lombok lainnya. Ia menulis-kan, "kemarin di Lombok Tengah, saya 
menyerahkan langsung beasiswa dari pemerintah kepada tujuh orang yang mewakili 5.144 mahasiswa penerima beasiswa di NTB. Dengan beasiswa ini, saya berharap mereka bisa terus melanjutkan kuliahnya hingga ram-pung di berbagai perguruan tinggi di seluruh Indonesia”.

Tak hanya Palu dan Lombok, pada 24 Desember 2018, Joko Widodo kembali memposting tentang kepeduliannya terhadap korban bencana alam pada 24 Desember 2018. Saat itu, Joko Widodo menceritakan kegiatannya ketika menemui para pengungsi di Rancateurup. Joko Widodo juga mengunjungi para pengungsi yang dirawat di Puskesmas dan Rumah Sakit Lapangan Batalyon Kesehatan I Marinir Cilandak di Labuan. Di Instagram miliknya, ia memposting fotonya ketika melewati Pantai Mutiara di Pandeglang telah diterjang tsunami. Pada postingan tersebut, Joko Widodo menuliskan, "Segenap jajaran pemerintah terkait telah melakukan penanganan tanggap darurat pas-cabencana selekas mungkin untuk mencari para korban, melakukan evakuasi, pelayanan kesehatan, serta membuka posko-posko pengungsian di lokasi”.

Dari postingan tersebut, Joko Widodo juga merencakanan untuk memasukkan kurikulum kebencanaan ke dalam sistem pen-didikan di Indonesia. Joko Widodo menuliskan, "Melihat potensi bencana di Tanah Air dan banyaknya korban yang ditimbulkan, saya memandang perlu untuk memasukkan pendidikan kebencanaan dalam kurikulum. Dengan begitu, masyarakat mendapatkan pengetahuan sejak dini terkait kebencanaan sehingga dapat meminimalisir sejumlah korban". Penjabaran Joko Widodo di lokasi bencana mencerminkan bahwa pemerintah Indonesia selalu mengupayakan untuk cepat tanggap dan serius bekerja ketika mengatasi bencana alam di Indonesia. Pemerintah langsung sigap mencari korban di lokasi bencana, mendirikan fasilitas-fasilitas umum darurat, memberikan beasiswa untuk para pelajar di lokasi bencana, dan lain sebagainya.

Joko Widodo juga sering mengunggah foto ketika berkunjung ke tempat-tempat yang menerima kucuran dana desa dan mendapat ratusan ribu likes dari para pengguna akun Instagram. Pada 24 Oktober 2018, Joko Widodo memposting foto yang membahas tentang penggunaan dana desa di berbagai tempat di Indonesia. Pada foto tersebut, tampak Joko Widodo sedang berdiri di samping orang-orang yang bekerja untuk membangun infrastruktur di desa mereka. Joko Widodo meyakinkan, dengan dana desa yang diturunkan oleh pemerintah pusat, desa dapat berkembang menjadi lebih baik lagi.

Sementara itu, pada Februari 2019, Joko Widodo kembali mengunggah foto dan tulisan di Instagram miliknya. Ia menegaskan kembali tentang dana desa, bahwa program yang dijalankan oleh setiap desa wajib menyesuaikan dengan keunggulan pada desa tersebut. Desa 
yang memiliki pemandangan alam maupun objek wisata yang menarik perhatian pengunjung, dapat mengerjakan hal-hal tersebut untuk menambah penghasilan di desa itu sendiri sehingga dana desa tidak terbuang sia-sia.

Selain post mengenai bencana alam dan dana desa, Joko Widodo juga sering memposting foto dan video tentang atlet. Pada 2 Oktober 2018, Joko Widodo mengunggah fotonya di Istana Merdeka bersama para atlet Asian Para Games. Ia mengenakan batik dan berada di tengah-tengah atlet berbaju merah yang menderita disabilitas. Pada post tersebut, akun Instagram Joko Widodo menuliskan, "Sebagai tuan rumah, Indonesia menurunkan sebanyak 296 atlet di Asian Para Games 2018 di Jakarta. Mereka akan berlaga di 18 Cabang Olahraga. Pagi ini, di halaman ten-gah Istana Merdeka, saya melepas kontingan Indonesia dnegan harapan yang tinggi agar mereka menunjukkan kemampuan terbaik da-lam persaingan antarnegara di Asian Para Games 2018 mendatang. Saya sudah melihat langsung bagaimana mereka berlatih untuk mempersiapkan diri. Dari latihan keras itu, saya berani menargetkan posisi delapan besar dan 16 emas. Selamat berjuang di palagan olahraga Asian Para Games 2018”.

Selain post tersebut, Joko Widodo juga mengunggah tentang salah satu atlet disabilitas yang duduk di atas kursi roda sambil me-megang anak panah. Foto ini menarik per-hatian dari para warganet yang hadir di kolom komentar. Beberapa warganet mengomentari bahwa atlet-atlet menjadi berjaya ketika Joko Widodo hadir sebagai pemimpin negara Indonesia. Terkait tentang hal itu, tertulis di cnnindonesia.com (2018) menuliskan, di era Joko Widodo, terdapat plus dan minus untuk dunia olahraga di Indonesia. Untuk minusnya, Indonesia tidak meraih penghargaan apa-apa di SEA Games yang digelar di Kuala Lumpur, Malaysia. Namun, untuk positifnya, Indonesia sudah meraih puluhan medali emas, serta memberikan kesetaraan bonus untuk para atlet disabilitas dan diberikan tepat waktu.

Dengan cara menaikkan derajat atlet-atlet, terutama atlet disabilitas di Indonesia, Joko Widodo lagi-lagi mendapatkan perhatian dari masyarakat Indonesia. Konten tentang atlet tersebut dapat menjadi batu loncatan Joko Widodo untuk memperoleh suara dari rakyat Indonesia pada pemilihan presiden 2019.

Selain mengunggah potret tentang pekerjaannya sebagai pemimpin negara, Joko Widodo juga mengunggah potretnya ketika ia sedang menghabiskan waktu santai bersama keluarga. Pada 9 Maret 2019, Joko Widodo memposting fotonya yang sedang menggandeng tangan Iriana di hutan karet Banyuasin. Foto tersebut mendapat respon positif dari pa-ra warganet. Pada kolom komentar, @na.azizz mengatakan bahwa Joko Widodo adalah sosok suami idaman yang mampu melindungi dan menjaga istrinya, sehingga sosok tersebut pan-tas 
memimpin negara. Beberapa warganet ju-ga menyatakan bahwa Joko Widodo dan ibu negara adalah pasangan yang romantis.

Tak hanya foto bersama istrinya, tapi juga foto bersama keluarga besar lainnya, terutama pada cucu pertanya. Pada post tang-gal 16 April 2019, Joko Widodo memposting videonya yang sedang berenang bersama cucunya, Jan Ethes. Lagi-lagi, video tersebut membuat warganet memujinya sebagai sosok kakek yang mencintai keluarganya. Video Jokowi yang yang berjudul 'Momong Jan Ethes' mendapat ratusan ribu likes dan komentar. Hasil dari penelitian menyebutkan, Ahok membangun manajemen kesan di depan warga Jakarta dengan strategi yang menekankan pada hal-hal yang sedang dan sudah ia lakukan. Selain itu, lewat media sosial, Ahok juga sering memposting kedekatan dengan anak-anaknya dan memberi mereka motivasi. Hal itu mendapat respon positif dari para warganet di DKI Jakarta, dimana respon positif tersebut mampu menjaring suara untuk memilih Ahok sebagai gubernur DKI Jakarta.

Strategi serupa juga dilakukan oleh Joko Widodo untuk memanajemen kesan tentang dirinya di Instagram. Berdasarkan penjabaran di atas, sebagai aktor di panggung 'Instagram' miliknya, Joko Widodo berusaha membangun impresi di depan para followers bahwa ia berperan sebagai individu yang berkompeten. Hal itu tampak dari postingan di Instagram tentang infrastruktur yang telah dibangun para era kepemimpinannya. Melalui unggahan tentang infrastruktur yang telah diresmikan olehnya, Joko Widodo sedang menampilkan prestasi yang terlaksana ketika ia memimpin negara. Joko Widodo menunjukkan kepada warganet tentang hal-hal yang telah dilakukan olehnya kepada publik.

Sementara itu, untuk membangun citranya sebagai pemimpin negara, Joko Widodo juga menggunakan strategi ingratitation, atau strategi menyenangkan orang lain. Strategi ini digunakan ketika ia melakukan blusukan di pasar, kampung, dan tempat-tempat lainnya. Joko Widodo membangun kesan dengan cara menampilkan emosi-emosi positif ketika berinteraksi dengan publik, suka membantu publik, dan menghargai kepent-ingan publik. Strategi ketiga yang digunakan oleh Joko Widodo adalah strategi exemplification, dimana Joko Widodo ingin diimpresikan se-bagai orang yang layak dijadikan contoh bagi masyarakat Indonesia. Tak heran, Joko Widodo kerap mendemonstrasikan kemampuannya dalam memimpin negara, seperti membangun infrastruktur, cepat tanggap terhadap bencana alam, bahkan untuk hal-hal seperti mampu menyenangkan keluarganya dan menjadi sosok pemimpin keluarga yang hangat. Hal ini terlihat dari post Joko Widodo di Instagram ketika meresmikan infrastruktur di Indonesia, berkunjung ke lokasi bencana, mengadakan kegiatan blusukan, dan juga post ketika ia menghabiskan waktu bersama keluarganya. 


\section{KESIMPULAN}

Setelah menganalisis frontstage Joko Widodo di akun Instagram @jokowi, Joko Widodo menggunakan tiga strategi dalam membangun kesan di hadapan audiens. Pertama, Joko Widodo menggunakan strategi self-promotion. Di Instagram miliknya, Joko Widodo mengunggah potret-potret keberhasilannya sebagai kepala negara, antara lain membangun infrastruktur di berbagai tempat di Indonesia, menjadikan harga pokok tetap stabil, mensejahterakan atlet-atlet di Indonesia, dan cepat tanggap dalam bencana alam.

Selain itu, Joko Widodo juga menggunakan artefak yang menjadi ciri khasnya, yakni baju putih dengan lengan digulung. Secara filosofi, Joko Widodo meyakini bahwa kostum tersebut mencerminkan bahwa ia bekerja untuk rakyat Indonesia dengan hati yang bersih. Hal ini sesuai dengan jargon khas Joko Widodo, “Kerja! Kerja! Kerja!”. Dari frontstage yang ditampilkan Joko Widodo di Instagram, ia membuat gambaran bahwa tidak ada jarak sosial antara ia dan masyarakat, meskipun status sosialnya berbeda. Hal itu terlihat dari unggahan Joko Widodo di Instagram ketika melakukan blusukan ke pasar tradisional dan berbincang dengan para pedagang di sana.

Untuk pengelolaan panggung Instagram miliknya, Joko Widodo mengandalkan tim di belakang layar, yakni Tim Komunikasi Digital Presiden. Tim tersebut bekerja di belakang layar Instagram akun@jokowi dan mendorong kesuksesan aktor Joko Widodo untuk membangun kesan di hadapan audiens, yakni followers dan pengguna Instagram lainnya. Strategi kedua adalah strategi ingratiation, atau strategi menyenangkan orang lain. Dengan strategi ini, Joko Widodo ingin dipersepsi sebagai individu yang menyenangkan dan ramah kepada audiens. Strategi ini diwujudkan oleh Joko Widodo melalui video yang diunggah di Instagram miliknya. Ia berupaya menularkan emosi-emosi positif ketika berinteraksi dengan orang lain yang ada di sekelilingnya. Tak hanya itu, Joko Widodo juga berusaha menularkan emosi positif kepada audiens yang menonton video di Instagram miliknya itu.

Strategi ketiga adalah exemplification, atau strategi bahwa Joko Widodo patut dijadikan sebagai panutan. Strategi ini memperlihatkan bahwa Joko Widodo ingin diimpresikan sebagai individu yang layak dijadikan contoh bagi orang lain. Untuk itu, Joko Widodo kerap mendemonstrasikan kemampuan-kemampuannya dalam berinteraksi dengan publik, membangun infrastruktur, mensejahterakan atlet, bahkan kemampuannya sebagai pemimpin keluarga. Hal itu dilakukan Joko Widodo dengan cara memposting gambar dan video tentang infrastruktur yang diresmikan, potretnya ketika melakukan blusukan, dan juga ketika berkumpul bersama keluarganya. Selanjutnya, perlu dilihat lagi bahwa sebagian besar pengguna dari Instagram ada-lah para generasi muda. Tak menutup kemungkinan bahwa 
terdapat kaum muda yang masih menjadi pemilih baru. Untuk itu, bagi para tokoh politik yang ingin membangun kesan melalui Instagram, disarankan untuk membuat konten-konten kreatif yang berkesan untuk kaum muda di Indonesia. 


\section{Daftar Pustaka}

Ardha, B. (2014). Social Media sebagai media kampanye partai politik 2014 di Indonesia. Visi Komunikasi, 13(1), 105-120.

Atmaja, N. B., \& Ariani, L. P. S. (2018). Sosiologi Media. Penerbit Rajawali pers.

Devito, J. (1997). Komunikasi Antarmanusia. Professional Books.

Hariati, Y. (2014). Persepsi Pemilih Pemula terhadap Political Personal Branding Joko Widodo (Studi Pada Anggota Komunitas Young on Top Malang). Diakses dari Penerbit Program S2.

Hasfi, N., Usman, S., \& Santosa, H. P. (2017). Representasi Kepemimpinan Calon Presiden Di Twitter. Jurnal ASPIKOM, 3(2), 270-284.

Jazuli.M. (2014). Sosiologi Seni. Graha Ilmu.

Kriyantono, rachmat. (2014). Teori Public Relations Perspektif Barat \& Lokal. Kencana Pranada Media Group.

Kumparan.com. (2018). KPU: Tidak Ada Batasan Kampanye di Media Sosial, Tapi Kami Pantau. 3.

Mauludi, S. (2018). Socrates Café. Kompas Gramedia.

Muchtar, K. (2016). Komunikasi Politik dan Pembentukan Citra Partai. Jurnal Ilmu Komunikasi UPN "Veteran."

Pratiwi, A. (2018). Representasi Citra Politik Harry Tanoesoedibjo (Studi Semiotika Roland Barthes Dalam Video Mars Partai Perindo). Profetik: Jurnal Komunikasi, 11(2), 17. https://doi.org/10.14421/pjk.v11i2.1426 